\title{
Effect of Integrated Nutrient Management on Yield of French Bean (Phaseolus vulgaris L.)
}

\author{
Sayma Parween* \\ Department of Horticulture, Birsa Agricultural University, Ranchi-834006, India \\ *Corresponding author
}

\begin{tabular}{|l|}
\hline Ke y w o r d s \\
$\begin{array}{l}\text { French bean, } \\
\text { Vermicompost, Pod } \\
\text { yield }\end{array}$ \\
\hline Article Info \\
\hline $\begin{array}{l}\text { Accepted: } \\
17 \text { November } 2019 \\
\text { Available Online: } \\
10 \text { December } 2019\end{array}$ \\
\hline
\end{tabular}

\section{Introduction}

French bean (Phaseolus vulgaris L.) $2 \mathrm{n}=22$ of family Leguminoseae (Fabaceae) is a short duration and one of the most precious and highly relished vegetables in North India. Pulses constitute the major part of Indian vegetarian diet that fulfills major share of protein requirement of predominantly vegetarian population of India. In India, many pulse crops are grown like mung, urd, gram and among these French bean is most important. French bean is an excellent source of protein. It is widely grown bean because of its short duration and nutritious values. It is a valuable source of protein, vitamins and minerals Hundred grams of green pods contain $22 \%$ protein, $78 \%$ of carbohydrates, 221 I.U. vitamin A, $11 \mathrm{mg}$ vitamin C, $381 \mathrm{mg}$ Calcium. It is rich in amino acids like tryptophan, 
methionine and some phenolic compounds like tannin and polyphenol oxidase [14]. Moreover, the protein of rajma has proved to be a quality protein for human consumption in the manner the soybean oil proved its worth.

French bean is assured crop which responds well to fertilization. It is especially characterized by lack of nodules though it is legume, due to absence of NOD gene regulator. It is inefficient in nitrogen fixation [3].

Therefore, it responds well to high nitrogen fertilization. There is a worldwide consensus that sole dependence on chemical input based agriculture is not suitable in long run and only integrated plant nutrient systems (IPNS) involving a combination of fertilizer, organic manure and bio-fertilizers are essential to sustain crop production, preserve soil health and biodiversity. In addition to this, organic manures help in improving the use efficiency of inorganic fertilizers.

Use of biofertilizers not only reduce the risk of environmental pollution but also bring the cost of cultivation. Vermicompost, FYM and biofertilizers are highly efficient organic manures, which can increase production and improve the quality of vegetables. These organic manures increase the fertility of land by increasing the NPK content, water holding capacity and productivity of soil. Organic manures have been the traditional means of maintaining soil fertility as it provides a balanced source of nutrient for crops and accelerate the biological activity.

The advantage of combining organic and inorganic sources of nutrients in integrated nutrient management has been proved superior. Therefore, keeping these facts in view, present study was undertaken to evaluate the influence of integrated nutrient management on yield of french bean.

\section{Materials and Methods}

A field experiment was conducted at Experimental farm of Department of Horticulture, Ranchi Agriculture College, Birsa Agricultural University, Kanke, Ranchi during rabi 2018-19. The mean annual precipitation of this region is $1400 \mathrm{~mm}$ of which $80-85$ percent is received during June to September. Temperature of this region varies as low as $6.00^{\circ} \mathrm{C}$ in winter to as high $37.70^{\circ} \mathrm{C}$ in summer and April and May are the hottest months with an average maximum temperature of $37.70^{\circ} \mathrm{C}$ and $36.80^{\circ} \mathrm{C}$, respectively while December and January are the coldest months of the year having temperature $6.00^{\circ} \mathrm{C}$. The relative humidity (R.H.) rises upto 87.00 per cent during November and February and falls down to 40.50 per cent during May

The soil of experimental field was sandy loam in texture (sand: $60.4 \%$, silt: $20.0 \%$ and clay: $19.6 \%$ ) with $6.1 \mathrm{pH}$, high in organic carbon $(0.57 \%)$ and low to medium in nitrogen (229.79 Kg/ha), phosphorus (35.40 Kg/ha) and potassium $(237 \mathrm{Kg} / \mathrm{ha})$. The experiment was carried out from Nov 2018 to March 2019 in Randomized Block Design (RBD) with 7 treatment replicated three times. The whole field was divided into three blocks, each representing a replication. The plot size was $9 \mathrm{~m} \times 9 \mathrm{~m}$ and the spacing was $40 \mathrm{~cm} \times 10 \mathrm{~cm}$. Treatments were allocated to each plot randomly using Fisher and Yates Random Number (1963).

Swarna Priya variety was taken for this experiment. Biofertilizer viz. Rhizobium and PSB (Phosphorus Solubilising Bacteria) were applied as seed treatment. Well decomposed vermicompost was incorporated in soil and mixed thoroughly as basal dose. Under each treatment, full dose of phosphorus, potash and $1 / 2$ dose of nitrogen (if to be given through fertilizer) 
were applied as basal dose and $1 / 2$ dose of nitrogen was applied as split one month after sowing. The source of nitrogen, phosphorus and potash were urea, SSP and MOP respectively. All cultural operations were performed as per recommendations. Sowing of healthy seed was done with spacing of $40 \mathrm{~cm} \times 10 \mathrm{~cm}$. Five plants form each plot were selected randomly and marked from each treatment to calculate number of pods per plant, length of pod, pod circumference, number of seeds per pod, seed length and yield of fresh pod per hectare.

\section{Results and Discussion}

The result of the present study indicated that among the 7 different treatments, the treatment combination of $\mathrm{T}_{5}[75 \% \mathrm{RDF}+25 \%$ (N) Vermicompost (1.25t/ha) + Bio-fertilizer (Rhizobium+PSB)] and $\mathrm{T}_{6}[75 \% \mathrm{RDF}+12.5 \%$ (N) FYM (1t/ha) $+12.5 \%(\mathrm{~N})$ Vermicompost $(0.625 \mathrm{t} / \mathrm{ha})+$ Bio-fertilizer (Rhizobium+PSB)] recorded significant improvement in various yield and yield attributing characters viz., number of pods per plant, pod length, pod circumference, number of seeds per pod, seed length and yield of pod per hectare (Table 1 and 2).

\section{Number of pods per plant}

The highest number of pods per plant (20) was found in T5 followed by 17.6 in T6 and 16.54 in $\mathrm{T} 3(75 \% \mathrm{RDF}+25 \%$ Vermicompost). T6(17.6) and T3(16.54) were at par to T5. The lowest pod number of 13.8 was observed in T7 i.e. 100 percent RDF. This might be because integrated use of chemical fertilizers, bio fertilizers and vermicompost increased the physical properties of soil (water and nutrient holding capacity). Availability of nutrient helps the plant to bear more number of flowers and reduce the chance of flower and fruit drop, as a result, more number of pods per plant are obtained. This result is in consonance with [2], [7] and [9] in French bean (Fig. 1).

\section{Pod length and pod circumference}

The maximum pod length $(11.01 \mathrm{~cm})$ was recorded in the treatment $\mathrm{T} 5[75 \% \mathrm{RDF}+25 \%$ Vermicompost + Biofertiizer (Rhizobium and PSB)], followed by $\mathrm{T} 6(75 \% \mathrm{RDF}+12.5 \%$ $\mathrm{FYM}+12.5 \%$ Vermicompost + Biofertilizer), $\mathrm{T} 3$ (75\% RDF + 25\% Vermicompost), T1(50\% $\mathrm{RDF}+25 \% \mathrm{FYM}+25 \%$ Vermicompost), $\mathrm{T} 2(75 \% \mathrm{RDF}+25 \% \mathrm{FYM}), \mathrm{T} 7[100 \% \mathrm{RDF}$ (Chemical treatment)] and T4[75\%RDF + 25\% FYM + Biofertiizer (Rhizobium + PSB)], having values $10.67,10.43,10.09,9.90,9.21$ and 9.12. Statistically it was observed that T6 was at par to T5 but, was significantly higher than other treatments and the minimum value (F9.1) of pod length was obtained in the treatment $\mathrm{T} 2$. It is evident from the data that pod circumference was highest $(3.16 \mathrm{~cm})$ in T5[75\%RDF $+25 \%$ Vermicompost + Biofertiizer (Rhizobium + PSB)], followed by $\mathrm{T} 3(75 \% \mathrm{RDF}+25 \%$ Vermicompost) with $3.10 \mathrm{~cm}$ and $\mathrm{T} 1(50 \% \mathrm{RDF}+25 \% \mathrm{FYM}+25 \%$ Vermicompost) with $2.92 \mathrm{~cm}$. From statistical analysis, it was evident that $\mathrm{T} 3$ and $\mathrm{T} 1$ were at par to $\mathrm{T}$. The minimum value $(2.68 \mathrm{~cm})$ was recorded in $\mathrm{T} 7$ (100\%RDF).

The higher length and girth of the pods might be due to the synergistic effect of organics and biofertilizer in making available more of plant nutrients by improving the soil physical health and solubilizing the nutrients in soil. The increased vegetative growth, balance C: $\mathrm{N}$ ratio and increased accumulation of carbohydrates, in turn might have increased pod size. The results are in confirmation with [9], [10] and [4].

\section{Number of seeds per pod}

The highest number of seeds (7.73) was recorded with $\mathrm{T} 2(75 \% \mathrm{RDF}+25 \% \mathrm{FYM})$ 
followed by 7.50 in $\mathrm{T} 6(75 \% \mathrm{RDF}+12.5 \%$ FYM $+12.5 \%$ Vermicompost + Biofertilizer) and 6.56 in $\mathrm{T} 5[75 \% \mathrm{RDF}+25 \%$ Vermicompost + Biofertiizer (Rhizobium + PSB)]. The lowest number of seeds per pod of 5.97 was found with $\mathrm{T} 7(100 \% \mathrm{RDF})$. This indicates that $100 \%$ RDF through chemical fertilizer produced some impact on growth but yield attributing characters were much influenced by supplemental organic source which changed the soil condition making it favorable for influencing the economic traits controlling yield. Increase in number of pods per plant, length of pod and number of seeds per pod were also reported by [5], [1] and [11].

\section{Seed length}

Maximum seed length of $1.84 \mathrm{~cm}$ was recorded in the treatment T5[75\%RDF $+25 \%$ Vermicompost + Biofertiizer (Rhizobium and PSB)], followed by $\mathrm{T} 6(75 \% \mathrm{RDF}+12.5 \%$ FYM $+12.5 \%$ Vermicompost + Biofertilizer) i.e. $1.76 \mathrm{~cm}$ and $\mathrm{T} 3(75 \% \mathrm{RDF}+25 \%$ Vermicompost) i.e. 1.72. Statistically, it was observed that $\mathrm{T} 6$ and $\mathrm{T} 3$ was at par to $\mathrm{T} 5$ and the minimum value $(1.27 \mathrm{~cm})$ of seed length was obtained in the treatment T9 (absolute control). It might be due to production of more amounts of food materials and accumulation of potash in the seed. The above findings are in harmony with [8] and [6].

\section{Hundred seed weight}

From the close observation of data (Table 3), it is evident that among different treatments the maximum value of hundred seed weight of French bean was recorded in T6[75\%RDF + $12.5 \%$ FYM $+12.5 \%$ Vermicompost + Biofertilizer (Rhizobium+PSB)] i.e. 49.71g, which was significantly superior than rest other treatments. The minimum value $(46.09 \mathrm{~g})$ of 100 seed weight was recorded in T7. It might be due to production of more amounts of food materials and accumulation of potash in the seed. Increase in photosynthetic area and translocation of photosynthates in plants, subsequently accelerated the formation of large-sized seed. The above findings are in harmony with [2], [6] and [8].

Table.1 Treatment details

\begin{tabular}{|c|c|}
\hline Treatment & Treatment details \\
\hline $\mathrm{T}_{1}$ & $50 \% \mathrm{RDF}+25 \%(\mathrm{~N}) \mathrm{FYM}(2 \mathrm{t} / \mathrm{ha})+25 \%(\mathrm{~N})$ Vermicompost $(1.25 \mathrm{t} / \mathrm{ha})$ \\
\hline $\mathrm{T}_{2}$ & $75 \% \mathrm{RDF}+25 \%(\mathrm{~N}) \mathrm{FYM}(2 \mathrm{t} / \mathrm{ha})$ \\
\hline $\mathrm{T}_{3}$ & $75 \% \mathrm{RDF}+25 \%(\mathrm{~N}) \mathrm{Vermicompost}(1.25 \mathrm{t} / \mathrm{ha})$ \\
\hline $\mathrm{T}_{4}$ & $75 \% \mathrm{RDF}+25 \%(\mathrm{~N}) \mathrm{FYM}(2000 \mathrm{~kg} / \mathrm{ha})+$ Bio-fertilizer $($ Rhizobium $+\mathrm{PSB})$ \\
\hline $\mathrm{T}_{5}$ & $75 \% \mathrm{RDF}+25 \%(\mathrm{~N})$ Vermicompost $(1.25 \mathrm{t} / \mathrm{ha})+$ Bio-fertilizer $(\mathrm{Rhizobium}+\mathrm{PSB})$ \\
\hline $\mathrm{T}_{6}$ & $75 \% \mathrm{RDF}+12.5 \%(\mathrm{~N}) \mathrm{FYM}(1 \mathrm{t} / \mathrm{ha})+12.5 \%(\mathrm{~N})$ Vermicompost $(0.625 \mathrm{t} / \mathrm{ha})+$ Bio- \\
& fertilizer $($ Rhizobium+PSB $)$ \\
\hline $\mathrm{T}_{7}$ & $100 \% \mathrm{RDF}($ Chemical fertilizer $)$ \\
\hline
\end{tabular}

Table.2 Cropping history of the experimental field

\begin{tabular}{|c|c|c|}
\hline YEARS & KHARIF & RABI \\
\hline $2015-16$ & Tomato & Fallow \\
\hline $2016-17$ & Tomato & French bean \\
\hline
\end{tabular}


Table.3 Effect of INM on yield and yield attributing characters

\begin{tabular}{|c|c|c|c|c|c|c|c|c|c|}
\hline Treatment & $\begin{array}{c}\text { Number } \\
\text { of pods/ } \\
\text { plant }\end{array}$ & $\begin{array}{l}\text { Pod } \\
\text { length } \\
\text { (cm) }\end{array}$ & $\begin{array}{c}\text { Pod } \\
\text { circumfere } \\
\text { nce } \\
(\mathbf{c m})\end{array}$ & $\begin{array}{c}\text { No. of } \\
\text { seeds/p } \\
\text { od }\end{array}$ & $\begin{array}{l}\text { Seed } \\
\text { length } \\
(\mathbf{c m})\end{array}$ & $\begin{array}{l}\text { Hundred } \\
\text { seed } \\
\text { weight(g) }\end{array}$ & $\begin{array}{c}\text { Fresh } \\
\text { weight of } \\
\text { one pod } \\
\text { (g) }\end{array}$ & $\begin{array}{l}\text { Yield of } \\
\text { pod/plot } \\
\text { (kg) }\end{array}$ & $\begin{array}{l}\text { Yield of } \\
\text { pod/ha } \\
\text { (quintal) }\end{array}$ \\
\hline T1 & 15.07 & 10.09 & 2.91 & 6.20 & 1.58 & 47.99 & 9.57 & 6.97 & 77.51 \\
\hline T2 & 14.47 & 9.90 & 2.91 & 6.56 & 1.49 & 46.96 & 9.34 & 6.95 & 77.28 \\
\hline T3 & 16.54 & 10.43 & 2.92 & 6.27 & 1.72 & 47.44 & 10.45 & 7.96 & 88.56 \\
\hline T4 & 15.13 & 9.12 & 2.90 & 6.33 & 1.67 & 47.67 & 9.67 & 7.50 & 83.43 \\
\hline T5 & 20.00 & 11.01 & 3.17 & 7.73 & 1.84 & 48.05 & 11.16 & 8.81 & 97.93 \\
\hline T6 & 17.60 & 10.67 & 3.11 & 7.50 & 1.76 & 49.71 & 10.85 & 8.05 & 89.54 \\
\hline T7 & 13.87 & 9.21 & 2.68 & 5.97 & 1.53 & 46.09 & 8.75 & 6.94 & 71.99 \\
\hline Sem $( \pm)$ & 1.26 & 0.36 & 0.08 & 0.44 & 0.04 & 0.48 & 0.84 & 0.69 & 7.6 \\
\hline$\underset{(P=0.05)}{C D}$ & 3.89 & 1.11 & 0.25 & 1.37 & 0.14 & 1.48 & 2.59 & 2.11 & 23.44 \\
\hline $\mathrm{CV}(\%)$ & 13.45 & 6.22 & 4.81 & 11.53 & 4.59 & 1.74 & 14.56 & 15.70 & 15.68 \\
\hline
\end{tabular}

Fig.1

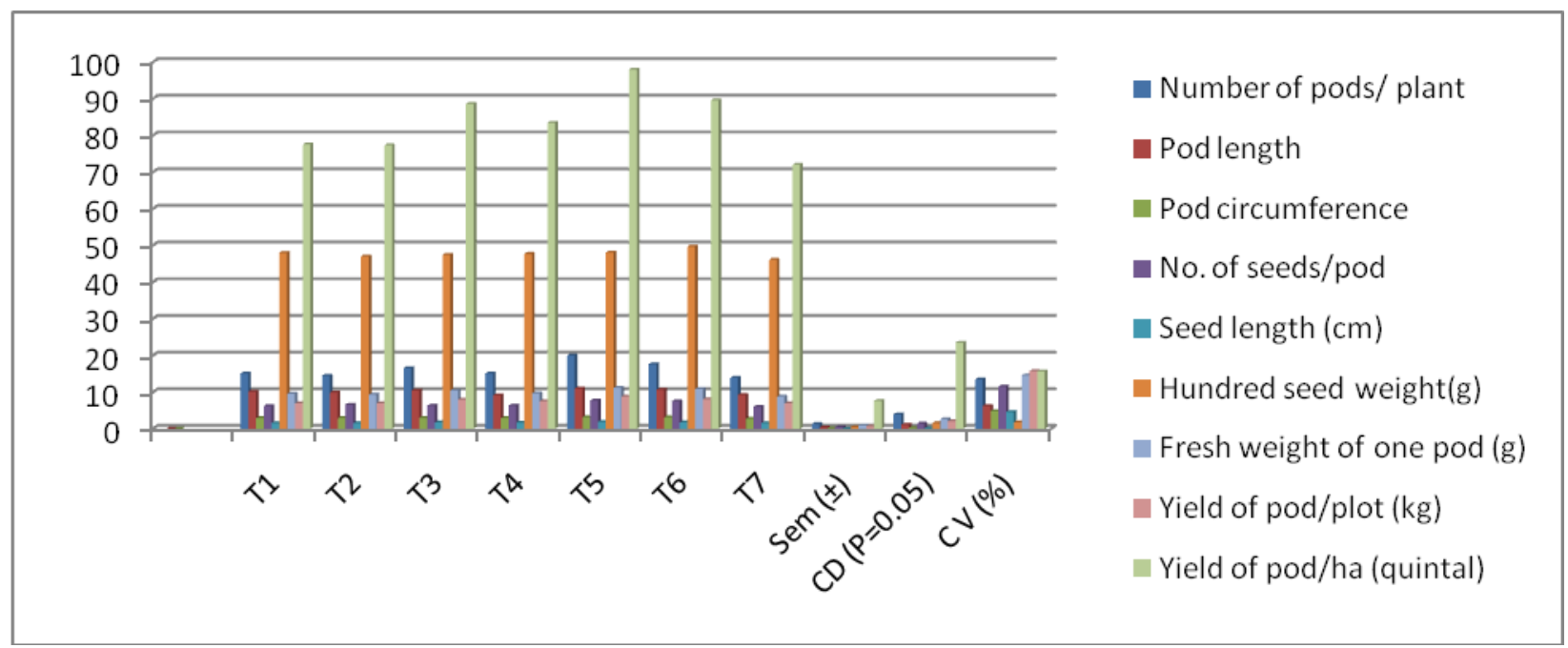

Yield per hectare

The maximum yield per ha was recorded in T5[75\%RDF $+25 \%$ Vermicompost + Biofertiizer (Rhizobium and PSB)] i.e. 97.93 quintal per hectare which was superior to all other treatments tried in experiment followed by 89.54 quintal in $\mathrm{T} 6(75 \% \mathrm{RDF}+12.5 \%$ FYM $+12.5 \%$ Vermicompost + Biofertilizer), 88.56 quintal in $\mathrm{T} 3(75 \% \mathrm{RDF}+25 \%$
Vermicompost), 83.42 quintal in T4[75\%RDF $+25 \%$ FYM + Biofertiizer (Rhizobium + PSB)], 77.28 quintal in $\mathrm{T} 7[100 \% \mathrm{RDF}$ (Chemical treatment)] and the lowest was recorded in T9 (43.17 q/ha) i.e. control. This might be due to gradual and steady release of nutrient from both vermicompost and bio fertilizers that help in plant metabolic activity, resulting in luxury vegetative growth followed by early reproductive phase. The increased 
synthesis of carbohydrates, accumulation of potash, in turn increased the pod yield.

Application of vermicompost and biofertilizers helped in improving soil health as well as facilitates slow and continuous supply of nutrient to the plant. The increase in yield might be due to the better performance of yield attributes as these attributes influence directly influenced the yield. The above obtained results were in harmony with [7] and [9].

It was observed that combination of organic and inorganic sources of fertilizer influenced yield attributing characters and also the yield. The application of vermicompost and biofertilizer in some treatments performed better with suitable nutrient combination. It can be concluded that application of $75 \% \mathrm{RDF}$ $+25 \%$ vermicompost along with biofertilizer produced better yield (97.93q/ha) as compared to other treatments.

\section{Acknowledgement}

Authors are very much thankful to the authorities of BAU, Kanke, Ranchi (Jharkhand), for providing all the necessary and required facilities to conduct the research.

\section{References}

Datt, N., Rana, M. C., \& Sharma, R. P. (2006). Effect of seed inoculation and farmyard manuring on nitrogen balance and yield in rajmash (Phaseolus vulgaris). Indian journal of plant physiology, 11 (1), 108-112

Ganie, Nisha, Ahmad, Sonalki, R.B. and Allie, Fayaz Ahmad. (2009). Effect of biofertilizers on growth and yield of garden pea (Pisum sativum L.). Asian J. of Horticulture, 4(2): 507-509.

Kushwaha, B. L. (1994). Response of frenchbean (Phaseolus vulgaris) to nitrogen application in north Indian plains. Indian Journal of Agronomy, 39(1): 34-37.

Manjunath, M. N., Patil, P. L., and Gali, S. K. (2010). Effect of organics amended rock phosphate and $\mathrm{P}$ solubilizer on $\mathrm{P}$ use efficiency of French bean in a Vertisol of Malaprabha Right Bank command of Karnataka. Karnataka Journal of Agricultural Sciences, 19(1): 30-35.

Mohanty, S., Sahu, G. S., Dash, S. K., Pradhan, S. R., Mangaraj, S., and Nahak, S. (2017). Integrated nutrient management for seed production in French bean (Phaseolus vulgaris (L.)). International Journal of Current Microbiology and Applied Sciences, 6(10): 3295-3303.

Negi, S., Singh, R. V., and Dwivedi, O. K. (2006). Effect of Biofertilizers, nutrient sources and lime on growth and yield of garden pea. Legume Research-An International Journal, 29(4): 282-285.

Ramana, V., Ramakrishna, M., Purushotham, K., and Reddy, K. B. (2011). Effect of bio-fertilizers on growth, yield and quality of French bean (Phaseolus vulgaris L.). Vegetable Science, 38(1): 35-38

Rana, N.S. and Singh, R., (1998). Effect of nitrogen and phosphorus on growth and yield of French bean (Phaseolus vulgaris L.), Indian Journal of Agronomy, 43: 367-370.

Rather, V., Ramakrishna, M., Purushotham, K. And Balakrishna, Reddy, K. (2010). Effect of biofertilizers on growth yield and economics of field pea (Pisum sativum L.). International Journal of Agricultural Science, 6(1): 65-66

Sahu, P. (2014). Integrated nutrient management in "Raika" French bean (Phaseolus vulgaris L.). M.Sc. Orissa University of Agriculture and 
Technology, Bhubhneswar, Orissa

Sharma, H. M., Singh, R. N. P., Singh, H., \& Roy Sharma, R. P. (1996). Effect of rates and timings of nitrogen application, growth and yield of winter rajmash. Indian Journal of Pulses Research, 9: 25-30.

Singh, B., Pathak, K., Verma, A., Verma, V., and Deka, B. (2011). Effects of vermicompost, fertilizer and mulch on plant growth, nodulation and pod yield of French bean (Phaseolus vulgaris L.). Vegetable Crops Research Bulletin, 74: 153-165.

Thakur, K.S., Dharmendra K. A., Vikram Thakur, A.K. and Mehta, O.K. (2010). Effect of organic manures and biofertilizers on growth and yield of tomato and French bean under mid hills of Himachal Pradesh. Journal of Hill Agriculture, 1(2): 176-178

\section{How to cite this article:}

Sayma Parween. 2019. Effect of Integrated Nutrient Management on Yield of French Bean (Phaseolus vulgaris L.). Int.J.Curr.Microbiol.App.Sci. 8(12): 2441-2447.

doi: https://doi.org/10.20546/ijcmas.2019.812.287 